\title{
Natural Products to Control Postharvest Gray Mold of Tomato Fruit- Possible Mechanisms
}

\author{
Firas Ali Ahmed, Brent S Sipes and Anne M Alvarez* \\ Department of Plant and Environmental Protection Sciences, 3190 Maile Way University of Hawaii at Manoa, Honolulu, HI, 96822, USA
}

\begin{abstract}
Grey mold is the one of most important postharvest disease of tomato fruit worldwide. Treatments with edible, natural products are needed to reduce losses and contribute to food sustainability. Based on the hypothesis that inhibition of Botrytis spore germination will significantly reduce postharvest losses, botanicals were tested for their effects on conidia. Ten Botrytis isolates from rotting tomato fruit collected at seventeen different sites in Hawaii were identified morphologically and confirmed by DNA sequence analysis. Effects of plant extracts on spore germination were assessed at several dilutions. Leaves of candidate biocontrol plants were frozen at $-20^{\circ} \mathrm{C}$ and plant fluids were sterilized by passing through a $0.22 \mu \mathrm{m}$ millipore. The effect of plant extracts on germination of Botrytis spores $\left(10^{6} / \mathrm{ml}\right)$ in sterile malt extract broth was evaluated in multi-well microplates using preparations ranging from 10 to $40 \%$. Changes in absorbance measured at 6,12 , and 24 hours after inoculation were analyzed with Gen5 software. Capsicum chinense cultivars Datil and C. annuum Carnival completely inhibited fungal germination at all evaluation times. Extracts from Capsicum species were superior to all other extracts tested. Treatments with $40 \%$ extracts increased the generation of intercellular reactive oxygen species in the fungal conidia. Plasma membrane damage was shown with fluorescence microscopy when extract-treated conidia were stained with propidium iodide. Loss of integrity in the spore plasma membrane appears to account for the inhibition of Botrytis spore germination. Extracts from the two pepper cultivars, Datil and Carnival, showed promise as pre-harvest sprays in the greenhouse and as edible coatings on tomato fruit postharvest to reduce grey mold.
\end{abstract}

Keywords: Postharvest diseases; Botrytis cinerea; Natural products; Reactive oxygen species; Membrane damage

\section{Introduction}

Tomato (Solanum lycopersicum Mill) is one of the most important vegetables produced globally. Fresh tomato production is highest among all vegetable crops in the U.S and the U.S. is a main producer of tomato in the world [1]. However, postharvest diseases of fruit and vegetables cause major losses in food production. Approximately 23$25 \%$ and $31-38 \%$ of harvested fruit are lost to postharvest spoilage in the USA and the world respectively [2]. Gray mold, caused by Botrytis cinerea, is considered one of the most destructive postharvest diseases of tomato in both field and greenhouse production where the temperature and humidity are conducive to fungal development [3]. Infection of tomatoes by $B$. cinerea causes major economic losses at the pre- and post-harvest stages [4]. Currently, synthetic fungicides are commonly used to control postharvest infections of $B$. cinerea [5].

Increasing international concerns for public health, excessive use of pesticides and development of fungal strains resistant to fungicides have resulted in the introduction of regulations and policies to limit use of synthetic pesticides over the past decades [6,7]. Alternative economically feasible approaches are needed to reduce postharvest gray mold of tomato fruit. Toward this end, antimicrobial characteristics of various plant extracts have been described for use in plant protection [8]. Many applications of substances, such as chitosan, extracts of Azadirachta indica seed, essential oils, medicinal plants, and mineral nutrients such as selenium, and borate have been investigated for control of postharvest fruit spoilage of fruit and several have been successfully applied [9-12].

Several plants in the family Solanaceae have antimicrobial and antifungal properties [13-15]. Pepper plants (Capsicum sp.) also have a wide range of uses, including pharmaceutical, natural pigment agents, cosmetics, and as ornamentals [16]. Phytochemical analysis of Capsicum species demonstrated that the presence of tannins, alkaloids, steroids, glycosides, flavonoids, phenols and terpenoid, provided a wide range of antimicrobial activities [17,18].
Waltheria indica is a woody plant belonging to the family Malvaceae. Waltheria is widespread in tropical and subtropical regions including Hawaii [19], South America [20], and South Africa [21]. Its antibacterial and antifungal activity has been documented in several studies $[22,23]$. The phytochemical investigation from the crude extract of $W$. indica indicated the presence of several chemical compounds such as alkaloids, flavonoids, tannins, sterols, terpenes, and saponins [24]. Scant information is available regarding the antimicrobial activity of pepper and Waltheria extracts on postharvest fungi or their modes of action.

In the present study, leaf extracts of Capsicum chinense (Datil), C. annuum (Carnival), C. frutescens (Hawaiian chili pepper), and Waltheria indica (sleepy morning) were tested as potential natural antifungal agents using spore germination of B.cinerea as a measure. The role of intercellular reactive oxygen species (ROS) and the integrity of the plasma membranes in relationship to germination of $B$. cinerea spores were also examined.

\section{Material and Methods}

\section{Fungal isolates}

Fungi were isolated from diseased tomato fruit collected from 37 markets located throughout the island of Oahu, Hawaii. Small sections $\left(1 \mathrm{~mm}^{2}\right)$ were excised from a range of lesions, incubated on water agar. Single hyphal tips were transferred to $\mathrm{V}-8$ agar in $9 \mathrm{~cm}$ petri dishes

*Corresponding author: Anne M Alvarez, Department of Plant and Environmenta Protection Sciences, 3190 Maile Way University of Hawaii at Manoa, Honolulu, HI 96822, USA, Tel: 8089567764; Fax : 8089562832; E-mail : alvarez@hawaii.edu

Received July 01, 2016; Accepted July 26, 2016; Published July 28, 2016

Citation: Ahmed FA, Sipes BS, Alvarez AM (2016) Natural Products to Contro Postharvest Gray Mold of Tomato Fruit- Possible Mechanisms. J Plant Pathol Microbiol 7: 367. doi: 10.4172/2157-7471.1000367

Copyright: (c) 2016 Ahmed FA, et al. This is an open-access article distributed under the terms of the Creative Commons Attribution License, which permits unrestricted use, distribution, and reproduction in any medium, provided the original author and source are credited. 
and incubated for 10 to $14 \mathrm{~d}$ at $20^{\circ} \mathrm{C}$ with a 12-h photoperiod [25]. The isolates were stored at $2^{\circ} \mathrm{C}$ in sterile soil for further study. Fresh cultures were established as needed by plating $0.2 \mathrm{~g}$ soil on $\mathrm{V}-8$ petri plates. Ten isolates of $B$. cinerea were selected for further study.

\section{Pathogenicity tests}

Tests were conducted to determine the most virulent isolates of $B$. cinerea on tomato fruit (common market, cherry and grape tomatoes), detached leaves and whole plants. Fruit were inoculated with mycelium of 10-day-old-cultures of the selected isolates of B.cinerea using 0.2-10 $\mu \mathrm{l}$ pipette tips. On the detached leaves, $6-\mathrm{mm}$ fungal plugs were placed on 4 -week-old surface sterilized tomato leaves placed in 9 -cm-d petri dishes including wet filter paper. The petri plates were held for $72 \mathrm{~h}$ at $23^{\circ} \mathrm{C}$ in the dark. On tomato plants, spore suspensions of $1 \times 10^{5}$ spores/ $\mathrm{ml}$ from 10-day-old cultures of each isolate of $B$. cinerea were prepared using a hemocytometer. Fungal spore suspensions were sprayed on 4 week-old tomato plants (Favorite, F1) growing in $10-\mathrm{cm}$-d plastic pots. The plants were placed in plastic bags, sealed, and held for $24 \mathrm{~h}$ at room temperature. Plastic bags were removed and plants returned to the greenhouse for 14 days. For disease assessment of tomato fruit and detached leaves, the lesion diameter of inoculated fruit and leaves were measured after $72 \mathrm{~h}$ at $23^{\circ} \mathrm{C}$. On tomato plants, the disease severity was scored on diseased plant utilizing a 0-5 scale.

The experiments were set up as Complete Randomized Design (CRD) with four replications. Data were analyzed using (SAS 9.2 V.USA) and means were compared by Duncan's multiple range tests. Differences at $\mathrm{p}<0.05$ were considered significant. All experiments were repeated three times.

\section{DNA extraction}

Fungal DNA was extracted from freshly collected mycelium of 10-day-old cultures using the Microbial DNA Isolation Kit (MO BIO, Laboratories, Inc.) according to manufactures' instructions. The concentration of extracted DNA was measured with a Nano Drop 1000 spectrophotometer (Thermo scientific, V 3.7., USA) and equilibrated using distilled water. Extracted DNA was stored at $4^{\circ} \mathrm{C}$ until used.

\section{PCR amplification}

The ITS region of the fungal isolates was amplified with the primer pair ITS3 (5-GCA TCG ATG AAG AAC GCA GC-3) and ITS4 (5TCC TCC GCT TAT TGA TAT GC-3) [26]. PCR was performed with a REDTaq DNA polymerase (Sigma, St. Louis, MO). A $20 \mu \mathrm{l}$ reaction mix contained $1 \mu \mathrm{l}$ of ITS 3 primer, $1 \mu \mathrm{l}$ ITS4 primer, $10 \mu \mathrm{l}$ REDTaq, $4 \mu \mathrm{lddH_{2 }} \mathrm{O}$, and $4 \mu \mathrm{l}$ of template. PCR was carried out using a Realtime PCR detection system (BIO-RAD) with initial denaturation for $3 \mathrm{~min}$ at $95^{\circ} \mathrm{C}$, followed by 36 cycles of denaturation for $30 \mathrm{~s}$ at $94^{\circ} \mathrm{C}$, primer annealing for $30 \mathrm{~s}$ at $55^{\circ} \mathrm{C}$, and extension for $1 \mathrm{~min}$ at $72^{\circ} \mathrm{C}$. A final extension for $5 \mathrm{~min}$ at $72^{\circ} \mathrm{C}$ was performed [27]. Each PCR reaction was run with a negative control (no DNA). The PCR products were electrophoresed on $1.5 \%$ agarose gels, stained with $0.4 \mu \mathrm{g} / \mathrm{ml}$ ethidium bromide, and bands visualized with a UV illuminator. DNA concentration estimates were calculated by comparing the fluorescent intensities of the product with DNA standards on a 2-log ladder (New England Biolabs, Inc.).

\section{Sequence analysis}

PCR product was cleaned using ExoSAP-1T (Affymetrix, Inc., USA). A mix of $5 \mu$ of post-PCR reaction and $2 \mu \mathrm{l}$ ExoSAP-IT reagents were combined. The mix was incubated at $37^{\circ} \mathrm{C}$ for $15 \mathrm{~min}$ following by incubation at $80^{\circ} \mathrm{C}$ for $15 \mathrm{~min}$. Each purified template was sequenced on both strands using two flanking primers (ITS3- ITS4) (ASGPB $\mathrm{Lab}$ ). The sequences of ITS 3 and 4 regions of the tested isolates were edited in order to generate a consensus sequence from forward and reverse sequences in the amplicon using sequence assembly software (DNA BASER). A consensus sequence was analyzed by NCBI BLAST database seeking fungal identities.

\section{Plant extraction and multi-well plates}

Leaf extracts were made from C. chinense, C. annuum, and C. frutescens obtained from Waimanalo Research Station and $W$. indica obtained from H1/University Ave (Native Hawaiian Plant Demonstration Site). Plant materials were extracted by following method described by [28] with some modification. Fresh plant material was collected in resealable plastic bags and placed in a freezer for a minimum of $12 \mathrm{~h}$ at $-20^{\circ} \mathrm{C}$. As plant material was tested, it was withdrawn from the freezer and allowed to thaw for a minimum of $20 \mathrm{~min}$. Freezing and thawing fractured the plant cells. The plastic bag was tilted so that the fluid collected in one corner, and extracted plant fluids collected in plastic weight boats. The extract was filter-sterilized by passing through a $0.22 \mu \mathrm{m}$ Millipore filter. Filtered 10, 20, 30, $40 \%$ extract solutions were prepared by adding $1,2,3$, and $4 \mathrm{ml}$ of sterile extract with 9, 8, 7, and $6 \mathrm{ml}$ respectively of a B.cinerea spore suspension $\left(1 \times 10^{5}\right.$ conidia $\left./ \mathrm{ml}\right)$ in sterile malt extract broth.

Fifty $\mu$ l of the plant extract and spore suspension mixture was pipetted into each well of a row of a 96 multi-well plate. A nontreated spore suspension was added to one row of each plate for comparison, and a blank row was included as an instrument check. Each well was sealed with a sheet of parafilm to prevent cross-contamination by volatiles. After $6,12,24 \mathrm{~h}$ incubation at $25^{\circ} \mathrm{C}$, the density of fungal growth in the wells was measured with an Epoch microplates reader (BioTek Instrument, Inc.). Absorbency/optical density was measured for each well using a 492-mm filter. Background readings from the average of the nontreated samples were subtracted by the Gene5 software program to provide net fungal growth in tested samples.

\section{Reactive oxygen species (ROS)}

A method using fluorescent probe 2,7-dichlorodihydrofluorescein diacetate(DCFH-DA)was used with slight modifications to assess the intercellular level of ROS in B. cinerea [12]. Spores of B. cinerea were cultured in malt extract broth supplanted with $40 \%$ C. chinense or C.annuum leaf extract and incubated for 2 , 4 , and $6 \mathrm{~h}$ at $23^{\circ} \mathrm{C}$. The spores of $1 \times 10^{5}$ per ml were collected and washed with $10 \mathrm{mM}$ potassium phosphate buffer ( $\mathrm{pH} 7.0)$ and incubated for $1 \mathrm{~h}$ in the same buffer containing $10 \mu \mathrm{M}$ DCFH-DA (dissolved in dimethyl sulfoxide).After washing twice with potassium phosphate buffer, spores were examined under a Zeiss microscope (Axioscop.A1, USA) using a fluorescein 2, 7- dichlorodihydro-specific filter. At least 100 spores were examined for each treatment with three replicates.

\section{Membrane integrity}

A propidium iodide (PI) staining method was used to detect the membrane integrity of $B$. cinerea conidia [29]. Spores of $B$. cinerea were cultured in malt extract broth medium supplemented with $40 \%$ of $C$. chinense C.annuum leaf extract and incubated 2,4 , and $6 \mathrm{~h}$ at $23^{\circ} \mathrm{C}$. The spores of $1 \times 10^{5}$ per $\mathrm{ml}$ were collected and stained with $10 \mu \mathrm{g} / \mathrm{ml}$ PI for $5 \mathrm{~min}$ at $30^{\circ} \mathrm{C}$. The spores were centrifuged and washed twice with $10 \mathrm{mM}$ potassium phosphate buffer ( $\mathrm{pH} 7.0$ ) to remove residual dye. The spores were observed under a Zeiss microscope (Axioscop.A1, USA) and red stained conidia were recorded. At least 100 spores were examined for each treatment with three replicates. 


\section{Statistical analysis}

All statistical analyses were performed using SAS software version 9.2 (SAS Institute Inc., Cary, NC, USA). Data were subjected to oneway analysis of variance (ANOVA). Where appropriate, means were compared suing Duncan's Multiple Range Test. Differences at $\mathrm{P}<0.05$ were considered significant.

\section{Results}

Ten Botrytis isolates were made from 33 pathogenic-fungal genera recovered from infected tomato in a previous survey. Based on the morphological characteristics of isolates, microscopic observations of their conidiophores and conidia, all were identified as Botrytis spp.

\section{Molecular identification}

A PCR product with expected size $370 \mathrm{bp}$ was amplified successfully for all fungal isolates (Figure 1). A NCBI BLAST web (http://blast. ncbi.nlm.nih.gov/Blast.cgi) for the ITS3-ITS4 region to determine fungal identity and found that sequence maximum identity of $>98 \%$ with other $B$. cinerea entries. In addition, the BLAST results of Botrytis isolates B03 and B09 matched $\geq 99 \%$ to B. cinerea base pairs.

\section{Pathogenicity tests}

The ten isolates of Botrytis spp. were highly variable with respect to disease on tomato fruit, detached leaves, and whole plant. The lesion diameter ranged from 70,32 , and 25 to $16,10,10 \mathrm{~mm}^{2}$ on common market, cherry, and grape tomato, respectively; lesion size ranged from 28 to $14 \mathrm{~mm}$ on detached leaves; and the severity scale ranged from 1 to 5 on whole plants, showing wide pathogenic variability. On tomato fruit, grey mold development differed on common market, cherry and grape tomatoes (Table 1). All isolates were pathogenic on the original host from which they were isolated. The largest lesion diameters on inoculated fruit were caused by $B$. cinerea $\mathrm{B} 03$, and were significantly in comparison to other isolates and the control (Table 1 and Figure 2). Necrotic lesions developed on detached leaves after $3 \mathrm{~d}$ for all isolates. Lesion diameters differed among Botrytis isolates with lesion size of B03 and B09 greater $(p<0.05)$ compared with other isolates (Figure 3). On whole tomato plants, isolate B03 was the most virulent among all the isolates 14 days after inoculation (Figure 4). B08 and B09 were less virulent on tomato plants. Other isolates varied in their disease severity. Since $B$. cinerea isolate B03 was the most virulent isolate; it was used for further study

\section{M1234567891011121314151617 M}

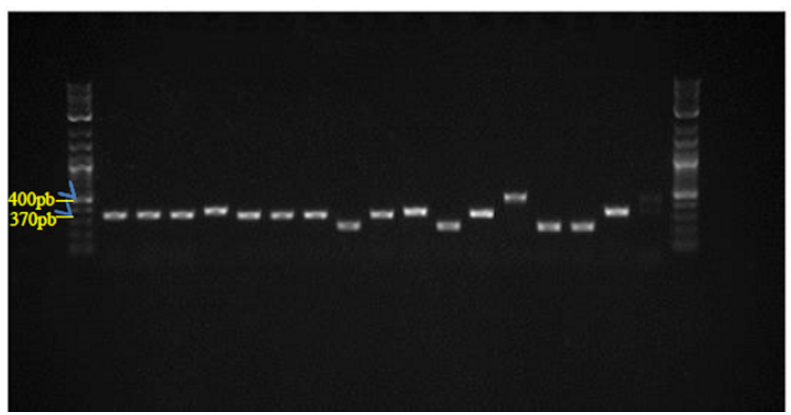

\section{Inhibitory effect of plant extracts on spore germination}

Plant extracts showing the greatest antifungal activity were those from $C$. chinense and C. annuum. Spores treated with these extracts at 30 and $40 \%$ concentrations showed significant differences compared to spores treated with broth (control) for all measurement of absorbance. Treated spores with these extracts registered under 0.1 absorbance in fungal growth after 6,12 , and 24 h. No significant differences were observed with the control were observed (Figure 5). An interaction between main treatments and all concentrations was not detected, indicating that the extracts effectively reduced Botrytis spore germination in all concentrations. The $40 \%$ C. chinense and C. annum extracts completely inhibited spore germination and fungal growth of B. cinerea after $24 \mathrm{~h}$ compared with the control (Figure 5). The extracts of $W$. indica and $C$. frutescens had intermediate antifungal activity against spore germination of B. cinerea at the 30 and $40 \%$ concentrations. The absorbance was less than 0.1 after 6 and $12 \mathrm{~h}$ but increased to more than 0.3 with $24 \mathrm{~h}$ of incubation (Figure 5). No effects were observed on spore germination with any of the plant extracts at the 10 or $20 \%$ concentrations (Figure 5). All plant extracts showed OD greater than 0.3 at concentrations of 10 and $20 \%$ after 24 $\mathrm{h}$ (Figure 5). Mycelia growth did not occur when spores were treated with extract concentrations of $40 \%$ in C. chinense or C. annuum after $24 \mathrm{~h}$. However, growth was less in spores treated with the same concentration of $W$. indica and C. frutescens extracts compared with the positive and negative control (Figure 5).

\section{Reactive oxygen species}

Reactive oxygen species generation was recorded when $B$. cinerea was exposed to $40 \%$ extracts of C. chinense cv. Datil and C. annuum $\mathrm{cv}$. Carnival for 0, 2, 4, and $6 \mathrm{~h}$ at $23^{\circ} \mathrm{C}$ (Figure 6). With an increased incubation period, the number of stained spores increased. The highest percentage of stained spores $92 \%$ and $66 \%$ for C. chinense and C. annuum extracts respectively. ROS of spores treated with the $40 \%$ extracts were greater compared with control treatment where 6\% ROS was observed (Figure 6). A majority of spores in the control treatment were not stained by DCFH-DA, implying poor ROS production at this time, indicating that an increasing amount of oxidizing molecules was produced in spores exposed to the extracts of $C$. chinense and $C$. annuum.

\section{Plasma membrane integrity}

With an increased incubation period, damage to cell membranes increased (Figure 7). The highest percentage of damaged plasma

M 18192021222324252627282930313233 M

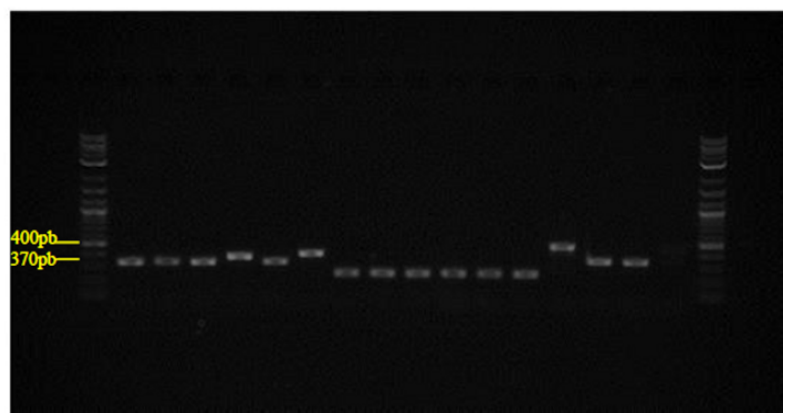

Figure 1: An amplified PCR products following gel electrophoresis using DNA from isolated fungi. $\mathrm{M}=\mathrm{Marker}(0.1-10.0 \mathrm{~kb}) ; 1-3=$ Botrytis sp.; $4=$ Rhizopus sp.; 5-6 = Botrytis cinerea; 7 = Botrytis sp.; 8 = Mucor sp.; 9-10 = Fusarium sp.; 11 = Penicillium. $12=$ Stemphylium sp.; 13=Colletotrichium sp.; $14-15$ : = Geotrichium sp.; 16 = Phoma sp.; 17 = NC (No DNA); 18-20 = Botrytis sp.; 21 = Alternaria sp.; 22 =Botrytis sp.; 23 = Fusarium sp.; 24-29=Geotrichium sp. 30 = Phoma sp.; $31-32$ = Mucor sp., 33 = NC (No DNA). 


\begin{tabular}{|c|c|c|c|}
\hline & \multicolumn{3}{|c|}{$\begin{array}{c}\text { Colony diameter }(\mathbf{m m}) \text { following inoculation onto fruit of } \\
\text { three tomato varieties }\end{array}$} \\
\hline Isolate ID & Common market & Cherry & Grape tomato \\
\hline B01 & $68.00^{\mathrm{a}}$ & $27.00^{\mathrm{b}}$ & $20.00^{\mathrm{b}}$ \\
\hline B02 & $30.00^{\mathrm{c}}$ & $22.00^{\mathrm{c}}$ & $10.00^{\mathrm{c}}$ \\
\hline B03 & $70.00^{\mathrm{a}}$ & $32.00^{\mathrm{a}}$ & $25.00^{\mathrm{a}}$ \\
\hline B04 & $30.00^{\mathrm{c}}$ & $12.00^{\text {de }}$ & $12.00^{\mathrm{c}}$ \\
\hline B05 & $30.00^{\mathrm{c}}$ & $16.00^{\mathrm{d}}$ & $10.00^{\mathrm{c}}$ \\
\hline B06 & $16.00^{\mathrm{d}}$ & $14.00^{\mathrm{de}}$ & $13.00^{\mathrm{c}}$ \\
\hline B07 & $59.00^{\mathrm{b}}$ & $22.00^{\mathrm{c}}$ & $18.00^{\mathrm{b}}$ \\
\hline B08 & $60.00^{\mathrm{b}}$ & $22.00^{\mathrm{c}}$ & $20.00^{\mathrm{b}}$ \\
\hline B09 & $61.00^{\mathrm{b}}$ & $25.00^{\mathrm{bc}}$ & $20.00^{\mathrm{b}}$ \\
\hline B10 & 59.00 & $10.00^{\mathrm{e}}$ & $10.00^{\mathrm{c}}$ \\
\hline Control & $1.00^{\mathrm{e}}$ & $1.00^{\mathrm{f}}$ & $1.00^{\mathrm{d}}$ \\
\hline
\end{tabular}

Mean values followed by different letters within a column are significantly different according to Duncan's multiple Range Tests $(p \leq 0.05)$.

Table 1: Pathogenicity of ten Botrytis isolates on common market, cherry and grape tomato after $72 \mathrm{~h}$ incubation at $23^{\circ} \mathrm{C}$.

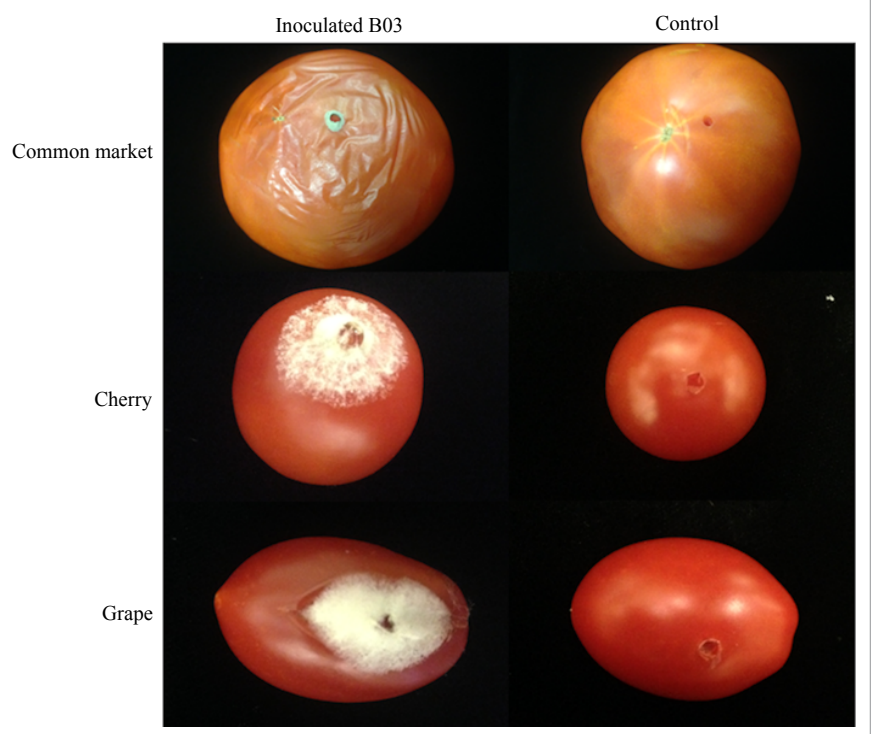

Figure 2: Lesions on tomato fruit inoculated with Botrytis cinerea B03.

membrane of stained spores was 89 and $51 \%$ for $C$. chinense and $C$. annuum extracts respectively following $6 \mathrm{~h}$ incubation. The control treatment had only $30 \%$ damage $(p<0.05)$ (Figure 7$)$. No difference was observed among treatments and control after 0 and $2 \mathrm{~h}$ incubation, indicating that an increasing of exposed period of spores to the extracts was needed to affect cell membrane integrity (Figure 7).

\section{Discussion}

The highly variable severity of symptoms caused by Botrytis isolates on tomato fruit, detached leaves, and whole plant suggest the existence of wide pathogenic variability among the isolates Pathogenic behavior of isolates is frequently as a result of deviation in cell wall degrades enzyme (CWDEs) activities and existence of oxalic acid and secretion pathogenicity factors [30,31]. High concentration of oxalic acid is associated with high level of pathogen virulence [32,33]. Some studies demonstrated that variation of Botrytis isolates in secreted polygalacturonases and pectin lyases contributed to the pathogenicity range of pathogens [34]. Other studies showed pathogenic behavior of isolates is associated with dispersal of a transposable element that contributes to pathogenicity and disease severity $[35,36]$.
Many natural fungicides occur in plants and can serve as safe alternatives to synthetic fungicides. Some compounds could be applied directly after formulated or serve as a pattern for artificial compounds. Pesticides resistance developed is a major problem in efficiency using of fungicide against Botrytis cinerea, such as Fenhexamid [37,38].

Most of plant species utilized in this experiment are edible and traditionally use in cured recipes [24,39]. Among them, Capsicum chinense (Datil) and C. annuum (Carnival) extract showed high antifungal activity followed by $C$. frutescens and Waltheria indica. Capsicum species extract were demonstrated to have a great antifungal activity against Botrytis cinerea [28]. The antifungal activity of Capsicum extract could be attributed by capsaicin, phenolic compounds, flavonoids, steroids, alkaloids, and tanins $[17,40]$. Although these extracts have been recognized possess of antifungal compound, they have not been developed into commercial product for postharvest treatments because industries utilize synthetic products as easier method. C. chinense and C.annuum extracts inhibited spore germination of B.cinerea. Capsicum extracts have potential as propitious antifungal agents as well as alternatives to synthetic fungicides for postharvest fungal infections. Capsicum extracts could be used as pre- and/or postharvest applications for protection of tomato fruit from gray mold disease.
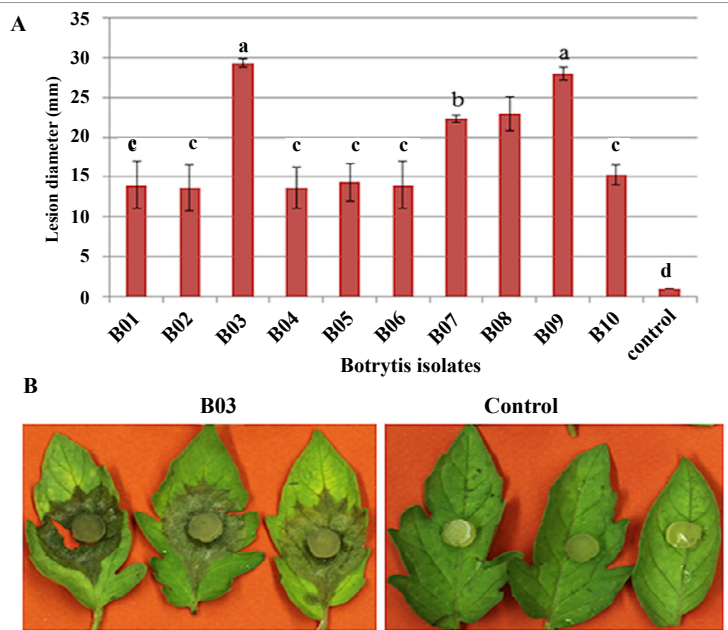

Figure 3: (A) Lesion diameter of ten Botrytis isolates $72 \mathrm{~h}$ after inoculation of detached tomato. Vertical bars indicate standard error $( \pm S E)$. Bars with the same letters are not significantly different according to the Duncan's multiple range test $(p \leq 0.05)$. (B) Leaf lesions caused by Botrytis cinerea (B03) $72 \mathrm{~h}$ after plug inoculation.
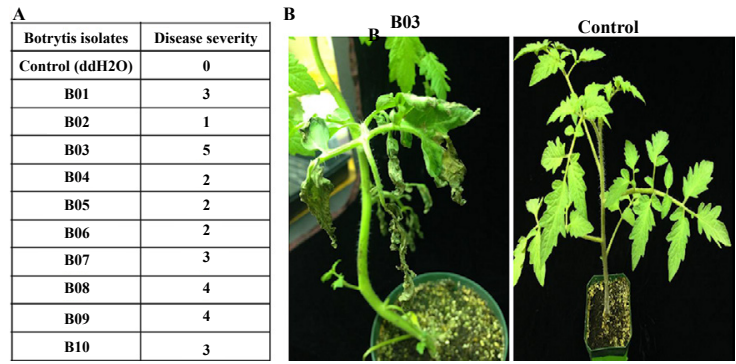

Figure 4: (A) Disease severity rating of Botrytis isolates following spray inoculation onto leaves of tomato (variety Favorite) (B) Symptoms caused by Botrytis cinerea (B03) two weeks after inoculation; Disease severity rating: (0) no lesions (healthy); (1) small number of lesions (almost healthy); (2) small number of lesions without died leaves; (3) small number of lesions with 1-5 dead leaves; (4) large number of lesions with 6-10 dead leaves; (5) large number of lesions with 11-20 dead leaves. 
A

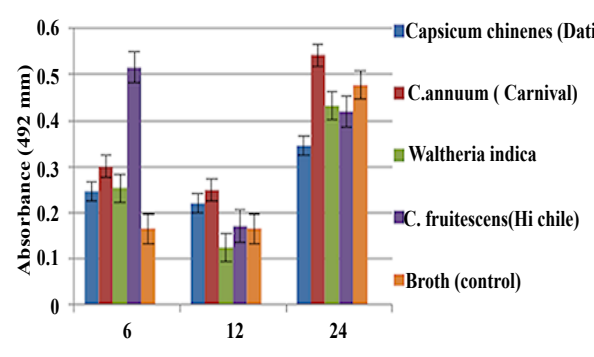

Time

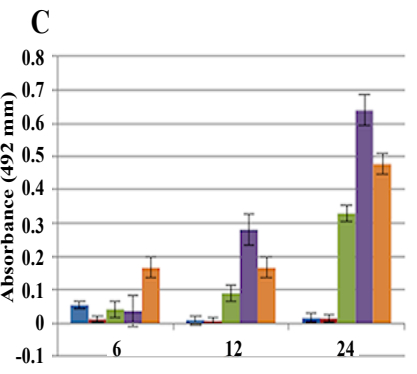

Time

\section{B}

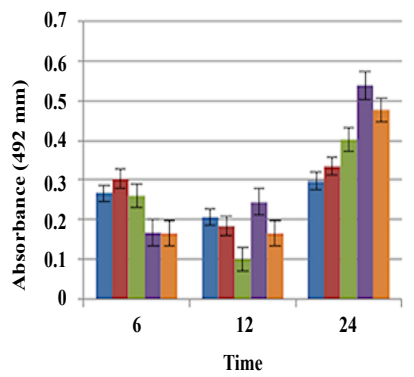

D

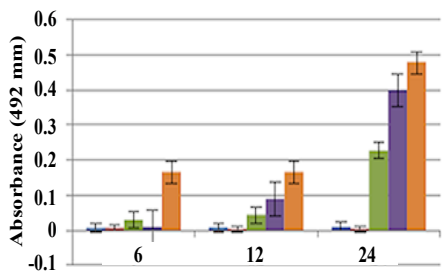

Time

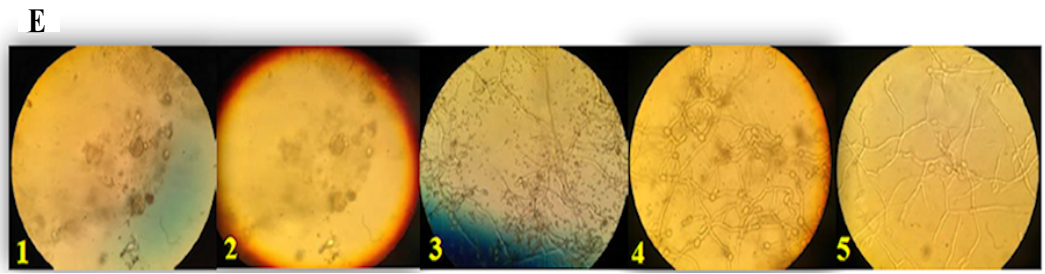

Figure 5: Effect of plant extracts on spore germination of Botrytis cinerea measured by absorbance of spore suspensions (492 mm) at $6,12,24 \mathrm{~h}$. (A) $10 \%$ (B) $20 \%$ (C) $30 \%$ (D) $40 \%$ (E) Micrographs of spores treated with $40 \%$ extracts after 24h of (1) Capsicum chinense (Datil); (2) C.annuum (Carnival); (3) C. frutescens (Hawaii Chile pepper); (4) Waltheria indica; (5); malt extract broth (control). Vertical bars indicate standard error $( \pm S E)$.
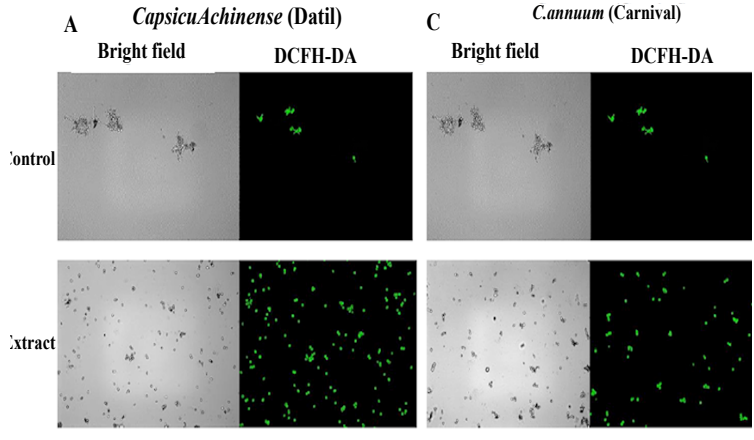

$6 \mathrm{~h}$

B

D
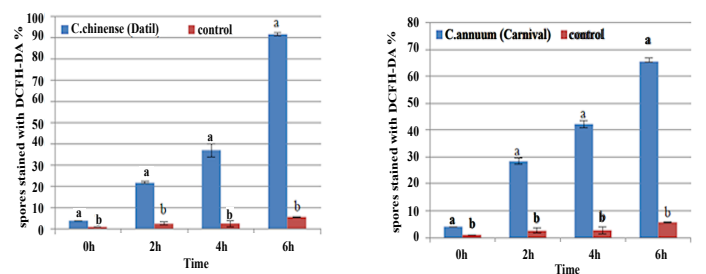

Figure 6: Effect of Capsicum chinense cv. Datil (A) and C.annuum cv. Carnival (B) extracts at $40 \%$ on production of reactive oxygen species in spores of Botrytis cinerea. (C) and (D) the percentage of spores stained with DCFH-DA. Spores incubated for $0,2,4$, and $6 \mathrm{~h}$. Vertical bars indicate standard error $( \pm S E)$. Columns followed by different letter are significantly different according to the Duncan's multiple range test $(p<0.05)$. 


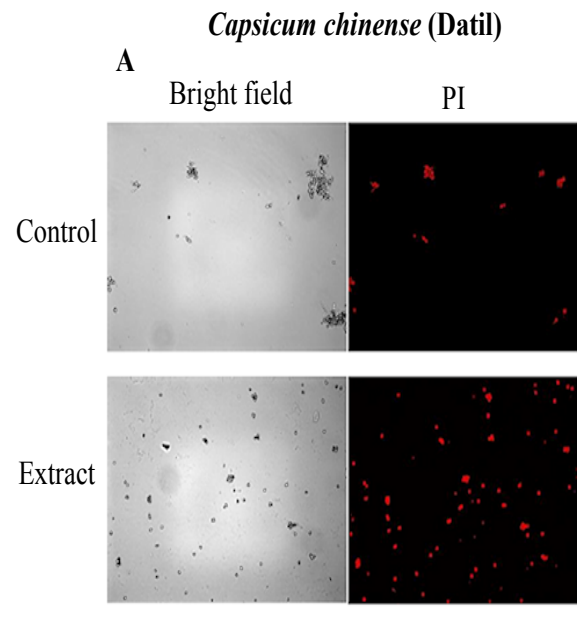

$6 \mathrm{~h}$

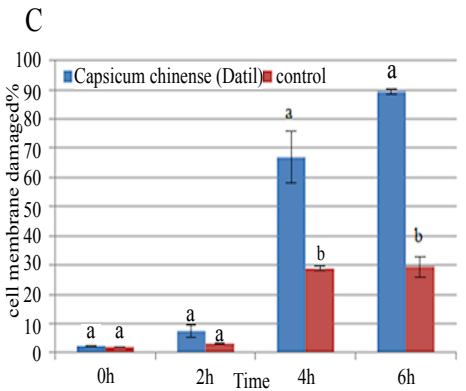

Capsicum annuum (Carnival)

Bright field

PI
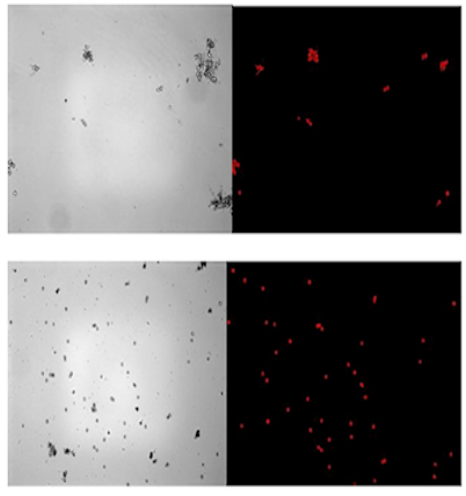

$6 \mathrm{~h}$

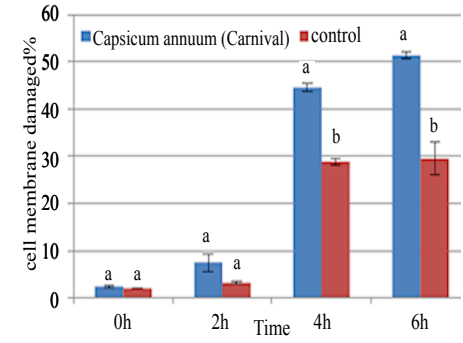

Figure 7: Effect of Capsicum chinense cv. Datil (A) and C. annuum cv. Carnival (B) extracts at $40 \%$ on cell membrane in spores of Botrytis cinerea. The percentage of cell membrane damage of spores treated with a $40 \%$ extract of $C$. chinense cv. Datil (C) or $C$. annuum cv. Carnival (D) and stained with propidium iodide. Spores were incubated for $0,2,4$, and $6 \mathrm{~h}$. Vertical bars indicate standard error $( \pm \mathrm{SE})$. Bars with the same letter are not different according to the Duncan's multiple range test $(p<0.05)$.

The mechanism of action associated with extracts of Capsicum seems to be related to production of ROS. Cellular dysfunction or cell death is a consequence of oxidative damage to cellular components caused by ROS $[12,29,41]$. ROS was induced by the Capsicum extract and inhibited spore germination of B.cinerea. PI staining implied that the accumulation of ROS in spore cells led cell membrane damage or reduced the intact membrane. Moreover, acknowledging of the mode of action of Capsicum extracts on their effects on B.cinerea would be useful for management of pre and postharvest application against gray mold. Consequently, further studies are needed on Capsicum extracts not only fungal pathogenic fungi but also on pathogenic bacteria that can also cause postharvest diseases on fruit and vegetables such as Pectobacterium sp.

\section{Conclusion}

Botrytis isolates differed in their virulence that was shown during the pathogenicity test. Also, we conclude that C. chinense cv. Datil and C. annuum cv. Carnival extracts at concentrations of $40 \%$ inhibited spore germination of B.cinerea. In addition, Capsicum extracts induce ROS generation in fungal spores, leading to oxidation and cell membrane damage. The oxidative damage could be the mechanism of Capsicum extracts against B.cinerea. These two natural products could be alternative to synthetic fungicide to control postharvest gray mold disease in tomato.

\section{Acknowledgments}

This research was supported by Higher Committee for Educational Development in Iraq and the University of Hawaii Foundation Program on Plant Disease Control.

\section{References}

1. USDA-ERS (2012a) Vegetables and Pulses Data.

2. Kantor LS, Lipton K, Manchester A, Oliveira V (1997) Estimating and addressing America's food losses. Food reviw 20: 3-11.

3. Elad Y, Williamson B, Tudzynski P, Delen N (2007) Botrytis: Biology, Pathology and Control Springer, The Netherlands.

4. Soylu EM, Kurt S, Soylu S (2010) In vitro and in vivo antifungal activities of the essential oils of various plants against tomato grey mould disease agent Botrytis cinerea. Int J Food Microbiol 143: 183-189.

5. Mari M, Francesco AD, Bertolini P (2014) Control of fruit postharvest diseases: old issues and innovative approaches. Stewart postharvest review 1: 1-4.

6. Holmes GJ, Eckert JW (1999) Sensitivity of Penicillium digitatum and P. italicum to Postharvest Citrus Fungicides in California. Phytopathology 89: 716-721.

7. Liu J, Sui Y, Wisniewski M, Droby S, Liu Y (2013) Review: Utilization of antagonistic yeasts to manage postharvest fungal diseases of fruit. Int J Food Microbiol 167: 153-160.

8. Del Campo J, Amiot MJ, Nguyen-The C (2000) Antimicrobial effect of rosemary extracts. J Food Prot 63: 1359-1368.

9. Bautista-Baños S, Hernandez-Lauzardo AN, Velazquez-Del Valle MG Hernández-López M, Barka EA, et al (2006) Chitosan as a potential natural compound to control pre and postharvest diseases of horticultural commodities. Crop Prot 25:108-118.

10. Emma O, Theresa N, Ucheoma O (2013) Control of postharvest bacteria diseases of tomato in Abia State, South Eastern Nigeria. Biol Agri Healthc 3:24-25. 
11. Ibrahim FA, Al-Ebady N (2014) Evaluation of antifungal activity of some plant extracts and their applicability in extending the shelf life of stored tomato fruits. J Food Process Technol 6: 1-6.

12. Wu Z, Yin X, Bañuelos GS, Lin ZQ, Zhu Z, et al. (2016) Effect of Selenium on Control of Postharvest Gray Mold of Tomato Fruit and the Possible Mechanisms Involved. Front Microbiol 6: 1441

13. Bosland PW (1996) Capsicums: Innovative uses of an ancient crop. Progress in new crops. ASHS Press, Arlington, VA pp: 479-487.

14. Dorantes L, Araujo J, Carmona A, Hernandez-Sanchez H (2008) Effect of capsicum extracts and cinnamic acid on the growth of some important bacteria in dairy products. Food Engineering: Integrated Approaches, (Springer).

15. Omolo MA, Zen-Zi W, Amanda KM, Jennifer HC, Nina LC, et al (2014) Antimicrobial properties of Chili peppers. J Infect Dis Ther 2: 145.

16. Brito-Argáez L, Moguel-Salazar F, Zamudio F, González-Estrada T, IslasFlores I (2009) Characterization of a Capsicum chinense seed peptide fraction with broad antibacterial activity. Asian J Biochem 3: 77-87.

17. Gayathri N, Sekar T, Gopalakrishnan M (2016) Phytochemical screening and antimicrobial activity of Capsicum chinense Jacq. Int J Adv in Pharmac 1: 12-20.

18. Vinayaka K, Prashith-Kekuda TR, Nandini KC, Rakshitha MN, Ramya, M, et a (2010) Potent insecticidal activity of fruits and leaves of Capsicum frutescens. Der Pharm Lett 2: 172-176

19. Abbott IA, Shimazu C (1985) The geographic origin of the plants most commonly used for medicine by Hawaiians. J Ethnopharmacol 14: 213-222.

20. Olajuyigbe O, Babalola A, Afolayan A (2011) Antibacterial and phytochemical screening of crude ethanolic extracts of Waltheria indica Linn. Afr J Microbiol Res 22: $3760-3764$.

21. Mathabe MC, Nikolova RV, Lall N, Nyazema NZ (2006) Antibacterial activities of medicinal plants used for the treatment of diarrhoea in Limpopo Province, South Africa. J Ethnopharmacol 105: 286-293.

22. Almagboul A, Bashir A, Salih A, Farouk A, Khalid S (1988) Antimicrobia activity of certain Sudanese plants used in folkloric medicine. Screening for antibacterial activity (V). Fitoterapia 59: 57-62.

23. Garba S, Salihu L, Ahmed M (2012) Antioxidant and antimicrobial activities of ethanol and $n$-hexane extracts of Waltheria indica and Mucona pruriens. J Pharm Sci Innov 5: 5-8.

24. Zongo F, Ribuot C, Boumendjel A, Guissou I (2013) Botany, traditional uses, phytochemistry and pharmacology of Waltheria indica L. (syn. Waltheria americana): a review. J Ethnopharmacol 148: 14-26.

25. Carisse O, Heyden HV (2014) Relationship of Airborne Botrytis cinerea Conidium Concentration to Tomato Flower and Stem Infections: A Threshold for De-leafing Operations. Plant Dis 1: 137-142.

26. Nikolcheva LG, Cockshutt AM, Bärlocher F (2003) Determining diversity of freshwater fungi on decaying leaves: comparison of traditional and molecular approaches. Appl Environ Microbiol 69: 2548-2554.
27. Evans TN, Watson G, Rees GN, Seviour RJ (2014) Comparing activated sludge fungal community population diversity using denaturing gradient ge electrophoresis and terminal restriction fragment length polymorphism. Antonie Van Leeuwenhoek 105: 559-569.

28. Wilson CL, Solar JM, El Ghaouth A, Wisniewski ME (1997) Rapid evalution of plant extracts and essential oils for antifungal activity against Botrytis cinerea. Plant Dis 2: 204-210.

29. Wu ZI, Ban JS, Li M, Bin YX, Qing LZ, et al (2014) Inhibitory effect of selenium against Penicillium expansum and its possible mechanisms of action. Curr Microbiol 69: 192-201.

30. Bellincampi D, Cervone F, Lionetti V (2014) Plant cell wall dynamics and wallrelated susceptibility in plant-pathogen interactions. Front Plant Sci 5: 228.

31. Kubicek CP, Starr TL, Glass NL (2014) Plant cell wall-degrading enzymes and their secretion in plant-pathogenic fungi. Annu Rev Phytopathol 52: 427-451.

32. Mbengue M, Navaud O, Peyraud R, Barascud M, Badet T, et al. (2016) Emerging trends in molecular interactions between plants and the broad hos range fungal pathogens Botrytis cinerea and Sclerotinia sclerotiorum. Front Plant Sci 422: 1-9.

33. Kumari S, Tayal P, Sharma E, Kapoor R (2014) Analyses of genetic and pathogenic variability among Botrytis cinerea isolates. Microbiol Res 169: 862-872.

34. Cotoras M, Silva E (2005) Differences in the initial events of infection of Botrytis cinerea strains isolated from tomato and grape. Mycologia 97: 485-492.

35. Samuel S, Veloukas T, Papavasileio A, Karaoglanidis GS (2012) Differences in frequency of transposable elements presence in Botrytis cinerea populations from several hosts in Greece. Plant Dis 9: 1286-1290.

36. Fournier E, Giraud T, Albertini C, Brygoo Y (2005) Partition of the Botrytis cinerea complex in France using multiple gene genealogies. Mycologia 97 1251-1267.

37. Angelini RMM, Rotolo C, Masiello M, Gerin D, Pollastro S, et al. (2014) Occurrence of fungicide resistance in populations of Botryotinia fuckeliana (Botrytis cinerea) on table grape and strawberry in southern Italy. Pest Manag Sci 70: 1785-1796.

38. Hahn M (2014) The rising threat of fungicide resistance in plant pathogenic fungi: Botrytis as a case study. J Chem Biol 7: 133-141.

39. Everitt JH, Drawe DL, Lonard RI (1999) Field guide to the broad-leaved herbaceous plants of South Texas used by livestock and wildlife. ( Texas Tech University Press, USA) p: 244.

40. Nascimento PL, Nascimento TC, Ramos NS, Silva GR, Gomes JE, et al (2014) Quantification, antioxidant and antimicrobial activity of phenolics isolated from different extracts of Capsicum frutescens (Pimenta Malagueta). Molecules 19 : 5434-5447.

41. Shi X, Li B, Qin G, Tian S (2012) Mechanism of antifungal action of borate against Colletotrichium gloeosporioides related to mitochondrial degradation in spores. Postharvest Biol Technol 67: 138-143. 